\title{
New Actors on Stage: Analysis of the Emergent Forms of Collective Action in the European Context
}

\author{
Dora Fonseca \\ Department of Sociology, Faculty of Economics, Centre for Social Studies (CES), \\ University of Coimbra, Coimbra, Portugal \\ Email: doraifonseca@gmail.com
}

Received 3 September 2013; revised 5 October 2013; accepted 13 October 2013

Copyright $@ 2014$ Dora Fonseca. This is an open access article distributed under the Creative Commons Attribution License, which permits unrestricted use, distribution, and reproduction in any medium, provided the original work is properly cited. In accordance of the Creative Commons Attribution License all Copyrights (C) 2014 are reserved for SCIRP and the owner of the intellectual property Dora Fonseca. All Copyright (C 2014 are guarded by law and by SCIRP as a guardian.

\begin{abstract}
In this article our focus will be on civil society's responses triggered by the imposition of the societies of austerity. The analysis will be centred on an emerging collective actor, the indignados, and on the conditions that fostered its formation and processes involved in the construction of its identity. To accomplish this task, we retrieved Ernesto Laclau's political logic of populism and the concept of political developed by Chantal Mouffe and applied them to the formation of the indignados' identity. This process is conceived in terms of the construction of antagonistic frontiers which divide the social into two opposing fields. This conception allows us to develop an analysis based on the notion of social conflict, as well as a reflection on the potentialities embodied by this new social actor, despite their presentation by the dominant discourse as utopic and therefore impossible. In this proposal, it is our aim to provide a better understanding of what is at stake when we talk about the indignados and a clearer perception of the political dimension of both struggle and resistance.
\end{abstract}

\section{Keywords}

Antagonism; Antagonistic Frontier; Civil Society; Conflict; Crisis; State

\section{Introduction}

The European context has, over the past years, been a privileged stage of emergence of new collective actors. 
These show distinctive features both in what concerns the modes of action adopted and the distance kept from the institutional dynamics. Their formation takes place within a context of profound changes that reveal the difficulties of contemporary societies in accommodating a number of processes of modernization. The unstoppable growth of unemployment, welfare state dismantling, labour markets segmentation, among other things, are imposing, on societies, transformations which have clear consequences on social relations and on previously constructed solidarities.

The European context (meaning the European Union countries) and its welfare state tradition are being affected by the proliferation of market ideologies and new production politics. The first, based on the imposition of ever rising profit rates, subsumes all human production to profitability goals, ignoring and trying to overcome the ontological dimension of work as human activity. The second, sustained by the reduction of work force by means of new technological solutions and decentralization policies directed at lowering the costs of production (relocation of production in areas of the globe with more flexible or almost inexistent labour legislation), has affected the job structure that had prevailed in these countries through the last quarter of the century.

Another important tendency giving its centrality to the structure of European societies is the "shrinking" of the welfare state. Even though this isn't exactly new (it began in the 1970's), it presents itself with a renewed impetus and a clearer goal: to reduce the state to a minimum by cutting out its social functions. Challenges posed by the "new order" are difficult to overcome, as well as undesirable, and represent a civilizational regression. Alternatives are needed and urgent and compete with the idea of inevitability installed. Institutional responses to crisis are clearly insufficient, lacking credibility and facing a set of limitations imposed by recent labour reforms guided by austerity's imperative. The new regime moves apace to establish itself as a rule.

Despite the widespread idea that ongoing changes are inevitable - a re-edition of the thatcherian maxim "there's no alternative" - civil society, or at least a part of it, does not conform to the fatalism of this political discourse aligned with the neoliberal project, and has been giving proofs of increasing dynamism and capacity of self-organization. The European territory is becoming more and more a locus of emergence of political actors and processes of contentious dynamics.

The collective actor we are referring to arises in the specific context of the society of austerity. Ferreira [1] defines austerity as an action-word that means the process of implementation of political and economic measures that lead to discipline and economic, social and cultural restraint. The application of this concept is inseparable from the idea of inevitability. What is unique about austerity is the recognition and acceptance of the idea that it is through individuals and their objective and subjective deprivation that solutions to crisis can be found, avoiding identifying where liability lies: whether on financial markets, public debt, or economic and social models adopted over the past years.

Crisis is being used as an argument and an instrument of subordination of workers, governments and even the entire societies to the will of global capitalism markets. According to the author, whose views we share, the austerity measures implemented have in consequence the deepening of labour precarity and fragility. In this context, the responsibility to "pay" for the crisis lies within individuals and their families. Citizens are urged to compromise, to be proactive and accept sacrifices. It seems that the responsibility to pay for the crisis lies first and foremost on individuals, through the application of austerity measures, whether by means of wage and social benefits cuts or suppression of conflict forms and labour rights (Serrano and Chafa, 2011 cit in [1]). This situation has triggered a reaction by civil society.

\section{Civil Society, Crisis and Counter-Hegemony}

In line with the previous section, our focus will be on the way civil society responds to the emergence and spread of this multifaceted crisis. This context has also triggered numerous solidarity expressions all around the world ${ }^{1}$. Before analysing more profoundly the reaction displayed, it is pertinent to explain what we mean by civil society. For that we will rely on the theoretical approach developed by Jean Cohen and Andrew Arato [2].

The concept of civil society defines a field threatened by the logic of administrative and market mechanisms and at the same time provides the main area of potential expansion of democracy under the so-called democratic-liberal regimes. The authors mentioned above emphasize the importance of differentiating civil society from political society of parties, political organizations, public policy (e.g., parliaments), and from an economic 
society composed of organizations of production and distribution.

In general, the political and economic society arise from the civil society and share with it some of their forms of organization and communication, and "constitutes itself by means of institutionalized rights (in particular, political and property rights), which are a continuation of the fabric of rights that ensure modern civil society” [2: p. 9]. What distinguishes civil society actors from political and economic actors is, first of all, the fact that the last participate directly in state power and economic production, trying to control them.

According to the authors, the forces of capitalist market economy can pose as much danger for social solidarity, social justice and empowerment of citizens, as for the administrative power. However, they safeguard that, in the context of liberal democracies, it would be a mistake to consider from the outset the opposition of civil society to the state and the economy. The antagonistic relationship of civil society, or of its actors, with the economy or the State only arises when mediations between them fail or when political and economic institutions act in order to isolate both decision making processes and who decides the degree of influence of organizations and social initiatives, as well as forms of public discussion.

The concreteness of the "threat" is visible in the case of countries that are being intervened by the triad IMF $^{2}$, $\mathrm{ECB}^{3}$ and European Commission (that is the case of Portugal), or where this possibility arises in the near future (the case of Spain, which is currently experiencing cuts in public expenses in order to avoid an intervention of that type). The countries that asked for external assistance are being forced to carry out a set of structural reforms in return for financial support, and most of the times, if not always, this has as consequence a substantial loss of national autonomy in what concerns political and economical matters. This is the context in which the antagonism opposing civil society, state and markets is drawn, that is, an antagonistic relation between civil society and a neoliberal societal project, and where takes place the emergence of the collective actors under study: the indignados ${ }^{4}$.

What we wish to point out, in order to open the discussion for the following sections, is that the "resurgence" of civil society - understood as the emergence of new collective actors, which operates through the establishment of an antagonism towards the economic and political society-is a direct response to the application of a new logic of governance aimed at the establishment of a society of austerity. At the centre of the debate are the oppositions defined by Jean Cohen and Andrew Arato: representative democracy vs. participative democracy, and welfare state defence vs. anti-neo-conservative statism.

It is acknowledgeable the emergence of a counter-hegemony in the neo-Gramscian sense, which, according to Carroll [3], refers to broad transformative strategies and practices for replacing the rule of capital with a democratic socialist way of life. In this sense, we must ask ourselves one question: are the emerging collective actors capable of effectively challenging power relations and bringing about a different and better future? The author advances that counter-hegemony, differently from defensive forms of subaltern resistance, makes an effort to shape Bloch's "anticipating elements", that are to become lasting features of social life which constitute the preconditions for "a post-capitalist future and to develop political strategy based on an analysis of those imamnent possibilities” [3, pp. 169-170]. Applying this to the field of collective action, social movements are the carriers of the new that reworks the old. But, as other social analysts have asked, under what conditions is it possible to defy the old order? What are the new combinations capable of counteracting the hegemonic order? The organic crisis is a crucial element in creating the new. In this kind of crisis, the structures and practices that constitute and reproduce the hegemonic order fall into chronic and visible disrepair, creating a new terrain of political and cultural contention, and the possibility (but only the possibility) of social transformation (Ibid).

Gramsci's concept of hegemony allows acknowledging the configuration of a new balance of forces in the political sphere, perceptible in the emergence of a new historical block that calls into question the consensus sustaining liberal democracies and the capitalist system. Gramsci [4] defines hegemony as the spontaneous consent given by the masses to the general direction imposed on social life by the dominant fundamental group, and this consent is historically caused by the prestige and confidence the dominant group enjoys because of its role in the world of production. Hegemony resides first and foremost in the realm of civil society, and involves a world view not only cherished by the dominant groups, but also actively supported and articulated by subordinate and allied groups. The concept explains how a particular group comes to exercise intellectual and moral leadership over other groups, leading the last to embrace the former's world view. This "necessarily supposes an

\footnotetext{
${ }^{2}$ International Monetary Fund.

${ }^{3}$ European Central Bank.

${ }^{4}$ The expression indignados could be translated as the outraged.
} 
intellectual unity and an ethic in conformity with a conception of reality that has gone beyond common sense and has become (...) a critical conception” [4, pp. 333-334]. Also, this notion implies that those who exert hegemony are aware and respect the interests of those over whom they exert it, and, therefore, the existence of a certain balance to which the first are committed [5]. In this sense, a crisis of hegemony, the rupture of the consensus, could be identified with the disregard of the dominant classes in what concerns the subaltern classes' interests.

The notion of "historical bloc" is intrinsically linked to that of hegemony and presupposes the existence of a connection between structure and superstructure, between the economic realm and ideology. The formation of a historical bloc depends on the existence of both a world view and a type of collective political action suitable to it. Though hegemony also comprises an economic dimension, for Gramsci it manifests itself, first and foremost, as an intellectual and moral direction, exerted on the cultural field and capable of building both consensus and the social base that supports it. Cultural institutions play a central role in the maintenance of the consensus and are responsible for fostering subordination through its imposition by non coercive ways. The existence of a collective will, as well as the conditions that enable its formation, is conceived in terms of whether the conditions for the development national-popular collective will are available. If a given formation is still in the economic-corporative phase, the construction of a national-popular collective will face serious constraints or will be impossible. Its construction depends on both the availability of possible alliances between different social groups and the development of an intellectual and moral reform which offers a new conception of the world.

A new and independent consciousness of the subordinated classes cannot be formed without the rupture of the consensus that sustained the "old order", without the breaking into pieces of the union around the traditional ideology (Ibid). The subaltern classes are the actor involved in the creation of a new historical bloc. This implies not only the creation of a new hegemonic system, but also a crisis of the ruling class' hegemony fosterer by its failure in the execution of a task or by the unexpected arousal of the masses and their participation in political life. As the ruling class looses the consensus upon which its hegemony is established, it is deprived of its leading status and becomes a dominant class which leans on the exercise of coercive force alone. The masses become disengaged from the dominant visions and the conditions for a war of position are set.

Carroll [3] mentions three parameters of hegemony that he considers to be central to early 21st century capitalism: postmodern fragmentation (fragmented collective identities and inculcation of a de-politicizing fascination with style and spectacle), neoliberalization of political-economic relations (deregulation which entails the insulation of a protected economic realm from popular power, accumulation by dispossession with the privatization of the public interest and promotion of possessive individualism) and capitalist globalization (increasing structural power of capital and neoliberal project of global governance). He considers that the hegemony exerted by the neoliberal historical bloc is far less inclusive than Fordism-Keynesianism (Cox, 1987 apud [3]). This has provoked a "cumulative decline in the capacity of hegemonic forms to promote and secure popular consent" that can be transformed into a window of opportunity within which a new ethico-political form comes into being, surpassing interests defined in instrumental and bringing formally disparate identities onto common ground [3, p. 173]. The counter-hegemonic project and its correlative social formation include not only class forces, but also other movements and identities that emerge from civil society. But, in other to be brought together, both class forces and civil society movements have to be willing to transform themselves and compromise with one another, adopting interests of others as its own.

\section{The Indignados}

The recent upheavals throughout Europe take place within the context of imposition of the societies of austerity. In countries like Portugal and Spain, which are amongst those affected, civil society is stage of emergence of new collective actors that contest the imposition of the neoliberal project. The indignados are perhaps the most expressive embodiment of the discontent felt by southern European citizens in what concerns the deep changes at stake. In the following lines, some key features of these mobilizations will be presented.

The indignados emerged in Spain and made the first appearance with the protest on the 15th May 2011, convened in more than fifty Spanish cities. They were direct or indirectly influenced by the Portuguese mobilization on the 12th March of the same year, when hundreds of thousands of people, led by dissatisfaction towards the political class and the successive Plans of Stability and Growth imposed by the government, poured onto the streets in protest, in several cities. They reclaimed their future and refused the lack of perspectives. The protest 
became known as Geração À Rasca, which is an expression that means something in between generation without future and generation with problems. It was joined by all those who identified themselves as being part of a generation that is facing a compromised future.

In general, the indignados protest against the system and, in particular, its political institutions and actors as they consider that they don't represent citizens' interests. The central issues are the limits of the representative democratic system, rising unemployment, labour reforms, structural reforms and their relation with poverty increase. All together, these problems work on to frustrate expectations about the future, especially those of upward social mobility. Young people, with levels of education and cultural capital higher than those of their fathers' generation, strongly believe to be destined to achieve a higher place in the social pyramid. So, the current situation represents the ultimate contradiction in what concerns the expectations they had, taken as unshaken truths, and the reality delivered. At the time being, a downgrading of both social status and life conditions is the most certain outcome. We believe this contradiction between objective and subjective positions to be the core reason for mobilization.

The indignados assume an anti-political parties' stance. They show scepticism concerning the way democracy functions nowadays and, therefore, put under surveillance the action of both political institutions and their actors. They claim to be promoters of a democratic project based on citizens' direct participation in decision-making processes and proclaim citizens' "right to the streets" ("the street is ours!"). The occupation of public spaces is seen as an important strategy of "struggle and organized resistance against the system" and is a central element in their repertoire. These occupations, by means of protests and popular assemblies, re-create the concept of agora and connect the recuperation of public spaces by citizens to the essence of democracy.

The Spanish mobilization, its features and timing, were strongly influenced by the events that had taken place in Portugal shortly before. It is perceptible a kind of contagion effect, suggesting the presence of learning processes and the modular character of the mobilization. Many young people were enthusiastic about the audacity of the Spanish indignados, who, against police repression, persisted on occupying a number of plazas (Spanish word for squares), being the most important occupation the one of Plaza del Sol in Madrid. It didn't take long for the Portuguese to follow this example and a few days later it took place the occupation of Rossio-an important plaza in the Portuguese capital city, Lisbon. Plazas' occupations became known as acampadas, which is a kind of urban camping that retrieves a well known form of public protest: the sit in. The acampadas played a central role in both countries. They attracted more and more people, all curious about the form of protest because it was different from traditional forms of action displayed by actors such as the trade unions. The acampada of Rossio was the starting point for the formation of movements' platforms inspired in the Spanish example and its claim of "real democracy, now!". The goals and forms of organization are similar in both cases, so we see no need to particularize neither the Spanish nor the Portuguese case, given the aim of this work.

The indignados follow collective action's contemporary tendencies, which are visible in their horizontal structure, reticular form and rhyzomic networks. They rely heavily on the use of new technologies as a means of communication (phone, internet and social networks) and cyberactivism plays a central role. It has enabled indignation's territorial widespread, putting in evidence the modular character of the mobilization [6,7].

The composition of the collective actor is strongly influenced by the new organization of work, guided by flexibility requirements that encompass mainly young people, women, immigrants, unemployed and all those who are somehow affected by market's refusal of rigidity ${ }^{5}$. It is not unreasonable to say that middle classes are the sector within which indignation arises. In that sense, it would be appropriate to consider the indignados in their relation with this sector of the population. According to Estanque, "the new sectors of precarious workers and unemployed highly qualified that have participation in the current indignados movement" are "fighting against a system that frustrates their perspectives of stabilization in a middle class life pattern" [8, p. 97]. If we place the indignados under the scope of new social movements, and admitting that the middle classes are, as said, the sectors within which indignation arises, the identification of new social movements with expressions of the petite bourgeoisie made by Klaus Eder [9] should be kept in mind. According to him,

"this type of collective protest is based on an objective structure which is characteristic of the petite bourgeoisie (...) it falls between all stools. It is not the upper class, neither the cultural class which represents the 'high' society nor the economic upper class. It is objectively locked out from the top, because it does not

\footnotetext{
${ }^{5}$ In this respect and in what concerns the indignados' discourse, we can easily identify in it the idea that the precarious workers of the XXI century have no place in fordist institutions as the trade unions.
} 
have the power to make its needs socially accepted and legitimate. (...) On the other hand, thanks to its control over the means of production and its state-guaranteed jobs, it did not become part of the proletariat. On the contrary, it can set itself apart from the bottom end of the class scale by condemning the instrumentalism of the lower classes and establishing its own needs as the true needs” [9, p. 145].

Eder links this ambiguity concerning the objective structure to the habitus of the new middle classes, which is determined by its situation in between the upper and the lower classes. According to this reasoning, the habitus of this middle class subject is objectively determined by the defence of individualization, which is imposed upon him by the status system. He defines the dilemma of the petit-bourgeoisie habitus as consisting in the incapacity of identification with either the objective position or the collective identity of the (upper) bourgeoisie; or with the objective position or the collective identity of the proletariat. In parts of the middle classes are taking place downgrading processes which are bringing the status position of these groups closer to that of the proletariat. The author establishes a relation between this situation and the emergence of forms of petit-bourgeois radicalism such as the political pressure group which stems from problems connected with the crisis of the welfare state, the frustration and disillusionment with the party system and with bureaucratization. This set of problems can be easily identified in the demands voiced by the indignados. However, we defend that they go well beyond being a political pressure group as they incorporate other sets of questions concerning the production and reproduction of society.

\section{Indignation, the Construction of a People and Antagonism}

Our goal is to understand how the indignados' identity is constructed and establish to what extent they can be considered a political actor. This task will be undertaken relying on the works of Ernesto Laclau and Chantal Mouffe, who have treated this subject in depth.

The indignados are a complex object of analysis. At first glance, it might look like that we're dealing with a set of very different individuals that are protesting against very different things. Despite the importance of the issues at stake, the indignados' demands seem to be too vague and are often understood as a mere positioning against the system, without proposing any solutions whatsoever. We try to contradict this kind of simplistic vision, which is very common and reduces both the indignados and indignation to mere expressions of discontent and revolt. We intend to accomplish that by demonstrating the process underlying the formation of the collective actor in question and its meaning given the specific context within which it occurs.

In his analysis of populism, Ernesto Laclau [10] applies three core categories in order to assess the construction of a people (pueplo in the original): discourse, empty signifiers and hegemony, and rhetoric. Even though when we speak of indignados we are not referring to a case of populism in the sense handled by Laclau, we consider these categories to be adequate for the analysis. The first category, discourse, is defined as the primary field of objectivity's construction and is conceived as a complex of elements within which relations play a constitutive role. This means that elements do not precede the relational complex, instead they are built through it; therefore relations play a central role. The construction of the actor indignados cannot be dissociated neither from the relational context in which it takes place—the society of austerity—nor from the actors which act within it—-the State, the markets and the international institutions.

The second category, empty signifiers and hegemony, requires a complex exercise. First, to understand conceptually a totality it is necessary to differentiate it from other thing distinct from it, and this other thing can only be a difference that fails in accomplishing its totalizing role as it is internal rather than external. The only way to constitute a true exterior will be if the outside is an excluded one (something the totality expels from within it in order to constitute itself). Given that equivalence is what subverts difference, all identity is constructed within the tension between the logics of equivalence and difference. The totality is always a failed one, impossible and necessary at the same time.

The indignados formation occurs by means of their differentiation from dominant discourse, which is here understood as the institutions and practices that convey the austerity discourse and the idea of inevitability. If they represent a difference, that means the indignados and the austerity discourse coexist inside the same system-the difference is internal, and therefore the totalizing isn't fulfilled. For the formation of an identity to take place it is required the constitution of an exterior which will only be a true one if it is excluded from the previous (dominant) system. A set of demands considering different but complementary issues, like labour is- 
sues, housing problems or the democratic system, are equally considered by this collective actor and constitute a chain of equivalences differentiated from the dominant discourse. The indignados' identity is constructed within a constant tension between the two logics mentioned.

There exists the possibility of a difference-without ceasing to be a particular difference- resentation of an incommensurable totality. This operation is particularly important for the analysis. Laclau calls it hegemony. As the totality involved is conceived as an impossible or unattainable object, the hegemonic identity is an empty signifier that transforms its uniqueness in a totality that is unattainable, but nevertheless a possible horizon. The concept of hegemony can be applied to the indignados: while being a difference in relation to the dominant system, the indignados assume the representation of all those who endure the negative effects of the system's neoliberal logics (the incommensurable totality): the people, the "99\%".

The third category, rhetoric, concerns the rhetorical displacements that occur whenever a literal term is replaced by figurative one. The notion of catachresis, recovered from classical rhetoric, is applied and means the impossibility of replacing a figurative term by a literal one. This figure is applied to the notions of hegemony and empty signifiers.

The accumulation of unsatisfied demands and the increasing inability of the institutional field in incorporating them in differential way lead to the establishment of equivalential relations. This situation involves the constitution of an internal frontier - that is, the dichotomization of the political field by means of the emergence of a chain of equivalences of unsatisfied demands - and, through this operation, the conversion of initial petitions in demands. We must clarify what we mean by political. We will draw on Chantal Mouffe's work, that conceives the political not as "a multitude of practices of conventional politics" (which she identifies with politics), but instead as the way society is instituted [11, pp. 15-16]. The political is understood as a space of antagonism and conflict, because the society's institution involves necessarily the drawing of an antagonistic frontier based on the logic of equivalences.

Laclau provides an elucidative example in this respect: a society that has as horizon the welfare state. In that case, the logic of differences would be the only legitimate form of constructing the social. In a society like this any kind of social need would be satisfied in a differential form and, in that sense, there would be no basis for the establishment of an internal frontier by means of condensation operations in which some privileged signifiers condense around them the meaning of an antagonistic field. However, the obstacles that one would expect to find in the process of institution of a society of this kind force its proponents to identify an enemy and to reintroduce the discourse of social division based on the logic of equivalence. Thus, the emergence of collective actors around the purpose of defending the welfare state is possible.

Popular demands, differently from democratic demands that are likely to be incorporated by the hegemonic formation in expansion, are the ones that challenge the hegemonic formation. The constitution of the first depends on the presence of an antagonism and on the drawing of an antagonist frontier. The last's function is to conceive society as two irreconcilable fields, structured around two incompatible equivalential chains. In this sense, the antagonism is a constitutive one and requires the existence of a fractured space. This fracture, which is closely related to the experiencing of a lack essential to the emergence of popular identities, represents a rupture in the continuity of the social, and without this initial rupture of the social order the emergence of an antagonism isn't possible. It is important to include in the equation those responsible for the frustration of the demand, to which the claims are addressed, as these are always directed at someone or something. Consequently, we find ourselves face to face with a dichotomous division between, on one hand, unfulfilled social demands and, on the other, the power that ignores the demands presented. This has often translation in the exclusion of the elements identified with power and, accordingly, their illegitimacy, as in the case of the indignados: they don't feel represented by the political power and therefore don't recognize it as having legitimacy to make decisions, especially in what concerns the austerity measures' implementation.

\section{Conflict and the Emergence of a New Political Subject}

The indignados are a reaction to the offensive displayed against the welfare state, carried out, objectively, through a set of structural reforms and, subjectively, by the active construction of a consensus based on acceptance and fear. Alain Touraine [12,13] identifies three dimensions that constitute social movements: identification of an opponent, identity and totality (the reasons for the conflict-a common set of values). The last of the three implies looking more deeply into the notion of conflict. For Touraine, the programmed society (which 
would be the one we live in) is necessarily a society of protest, imagination, utopia, because it is crossed by a social conflict between those who have the capacity and power of programming, and a call for creativity and constant happiness which are threatened by the logics of the apparatuses. The most important aspect of conflict is the clear definition of an adversary or opponent, and its non-negotiable character as it is defined on the grounds of shared cultural values by both opponents, who struggle about their appropriation. Hence, in a conflict we have actors who oppose each other about relations of domination and conflict. These actors share the same cultural orientations and struggle for the social control of cultural resources and values (Ibid).

The distinction between conflict and crisis is helpful in order to clarify the meaning that can be attributed to the indignados. Melucci says that "without a distinction between conflict and crisis it would be impossible to make sense of many historical and recent forms of collective action" [6, p. 22]. He correctly makes his point by giving the example of working class struggles: in the case of being mere reactions, as soon as the goals were accomplished the outcome would be subsequent demobilization. This evaluation stresses that the conflictual character of the workers movement has to do with a struggle against the very logic of the unequal power relation between capital and labour. Thus, it can't be classified as a mere reaction. For him, the appearance of collective action has often been linked to a crisis in the system, which would be the expression of a breakdown of the functional and integrative mechanisms of a given set of social relations. This argument implies considering collective action as pathology of the social system, giving it a negative sense. Differently, a conflict is defined by a struggle between two actors seeking to appropriate resources regarded by each as valuable. For an event to constitute a conflict, the actors must be definable in terms of a common reference system, and there must be something at stake to which them both, implicitly or explicitly, refer.

A conflict may be brought to the surface by particular situations of crisis internal to the system itself. But when a collective actor by its action makes visible a conflict which is antagonistic in nature, this should not be confused with a simple reaction. There is more to it than that. A crisis provokes disintegration and the subsequent reaction of those who seek to redress the balance, whereas an antagonistic conflict makes manifest a clash over the control and allocation of crucial resource [14]. It is not at all unusual the tendency of dominant groups to define social movements as mere reactions to crisis or, in another words, to reduce them to a dysfunctional mechanism of the system. This kind of classification underlines a negative content and prevents these groups from recognizing the existence of collective demands that challenge the legitimacy of power and the current deployment of social resources.

The social relations at work within the society of austerity's framework are perceived as damage. According to Rancière [15], a social demand corresponds to a subjective production from elements not previously identified and whose identification is concomitant with a new form of representation of the field experience. This new form of representation is involved in the questioning of dominant meanings fostered by the emergence of new demands. We come face to face with a new political subject, predisposed to action by the restructuring of meanings and the expansion of spaces of struggle for hegemony.

The emergence of this political subject results from the formation of an internal frontier due to the existence of an antagonism that separates the people from power. The construction of the people depends on the existence of an equivalencial articulation that puts together previously isolated demands. In this sense, the indignados are not only those who claim the right to a decent work, or even the right to have a job, but also those who, for instance, are concerned about the housing problem (which is a central preoccupation in the case of the Spanish indignados) or free education. Once mobilization has reached its highest level, the different demands are unified in a stable system of signification and are extended to other sectors or social groups that initially didn't think about these demands as theirs. In that sense, to be an indignado is to reject the ongoing changes as well as all sorts of inequalities, and to aspire for a better and more egalitarian future.

The structural transformations at stake make us rethink the validity of a form of politics in which the social division into two antagonistic fields is a given fact. According to Laclau and Mouffe, it is required a "transition towards a new situation, characterized by the essential instability of the political spaces in which the identity of the forces involved is subject to constant displacements and requires a process of continual redefinition” [16, p. 193]. That being so, the emergence of any collective identity depends on a process of generalization of the hegemonic form of politics, since the articulation practices — defined as one kind of hegemonic practice-determine the principle of the division of the social. The plurality and indeterminacy of the social is mandatory and therefore the points of rupture and conflict multiply.

The political requires the establishment of antagonistic frontiers within the social field and summons new 
subjects of social transformation. This involves the production of empty signifiers that allow the unification of the multiplicity of demands in heterogeneous chains of equivalences. The authors argue that resistance only arises as being political within a particular historical context, and as it ceases to be opposed to a specific instance of domination and starts being directed towards the disappearance of the whole structure of subordination. According to this argument, politicized resistance is discursively constructed, and the discourse of resistance only becomes politicized to the extent that the meaning of the democratic revolution is re-appropriated and redefined under certain historical conditions, combining the introduction of new meanings with the preservation of a non essentialist conception of previous articulations. The normalized forms of submission can now be seen as illegitimate and the elimination of subordination can be imagined by social actors.

The indignados are vehicle of a critique and rejection of liberal democracy and its domination system. This collective actor's discourse reflects the identification of the limits and contradictions of the same system that claims to be based on an egalitarian conception. Instead, it promotes a social order based on social inequalities, within which the meaning of democracy is distorted as it serves the capitalist interests that are identified with those of the dominant classes. There is, in the current system, an unsolvable conflict between egalitarianism and domination. The self-realization of individuals depends on the complete dismantlement of the relations of exploitation and oppression, and that implies both a new social order and new system. This matches formulations of authors such as Habermas [17,18], who consider that the market-oriented decision making in Western countries is extending itself to more and more spheres of human interaction and in a way that it conflicts with democratic principles.

The possibility of thinking the division of the social in terms of political frontiers emerges only once social division is no longer thought of as determined by a pre-existing objective space. According to Norval, "thinking social division in terms of political frontiers thus becomes increasingly important in situations where the political identities, emerging as result of the division of the social, do not correspond naturalistically to predesignated elements, but can clearly be seen to emerge as a result of a particular project's attempt to construct social and political identities in a specific manner” [19, p. 120]. Therefore, political and social identities are subject to political contestation and construction. In the indignados' case it is unquestionable the political dimension assumed by both struggle and resistance, as they contest vehemently the current social order and demand an alternative.

Marcuse [20] argues that contemporary industrial society demonstrates having reached the stage at which it can no longer be defined in the traditional terms of economic, political, and intellectual liberties. That puts in evidence the need for new modes of realization that would correspond to new capabilities of society. Freedoms linked to each one of the referred domains can no longer be defined within the current social system, and therefore the new modes can be referred to only in negative terms. In that sense, they amount to the negation of the prevailing modes. This argument applies to the indignados. They are widely criticized by dominant powers and the main reasons are absence of concrete proposals directed at social change and presence of an ideological void, as they refuse any kind of identification with the left-right dychotomic conception of politics. The first critique can be easily turned down by acknowledging the presence of the idea that it is necessary to come out with a new system. The utopic character ascribed by dominant discourse to the "vague" proposals of the collective actor is, as underlined by the Marcuse, not indicative of their unrealistic character, but of the strength of the forces which prevent their realization. In our case, the last would be the actors that are imposing the institution of the society of austerity. The role the indignados play in the deconstruction of the dominant discourse is essential. They deal with processes that present all contradictions as irrational and all counteraction as impossible. In that sense, a re-signification, a subversion of the dominant meanings is necessary and is established as a primary task.

\section{Conclusions}

The context of the societies of austerity and the emergence of the indignados are intrinsically linked. The last demands the construction of an alternative and does not yield to the widespread idea of inevitability. They represent civil society's response to the profound economic and political crisis. The turmoil that is felt across Europe highlights civil society's role as the privileged field of expansion of democracy within the framework of liberal democratic regimes. It is in this sense that we talk about a resurgence of civil society, here identified with the emergence of new actors and dynamics. Overall, the spaces of conflict multiply at an accelerated rate, constituting a trend in the current context. 
Indignation corresponds to a break in hegemony exerted by dominant classes. The wave of protests has eroded the consensus between neoliberal governance and representative liberal democracy, providing the base for a war of position. In that context, the construction of alliances between the subaltern and the dominated classes is utterly important. The indignados' protest is undertaken by an alliance that opposes the dominant world view, rejecting the consensus on it, and putting through an alternative world version. However, the presence of a new historical bloc cannot be taken for granted. It would be premature to do so given that it presupposes a new ideological-political direction (going beyond the economic-corporative unification of interests) and consensus as conditions of access to and maintenance of power. Instead, it could be said that the formation of a new historical bloc might be taking place. The indignados' organizational culture, claims and participation in formal politics are limited when compared with other political actors, but their emergence and modularity are congruent with an unexpected arousal of the masses. The existence of an intellectual and moral leadership isn't clear. Nevertheless, and despite these limitations, it is undeniable that the consensus that allows the ruling and dominant classes to impose their world view is being shaken, and thus a new balance of forces might be emerging.

The intensification of reactions to the imposition of the societies of austerity makes evident the outline of an antagonism. This opposes civil society to the state that gives its compliance with austerity politics. It is the configuration of this antagonism that shapes the indignados. The processes involved in their identity formation imply that, despite what dominant powers would want us to believe, the indignados are more than a mere expression of discontent. On the contrary, they can be looked at as being a product of a political logic (populism), which acts on the political field and gives shape to political resistance and struggle. Obviously, many valid questions can be asked about their structures and their consequences for the development of meaningful strategies and action. The indignados follow the contemporary trends of collective action characterized by flexibility, horizontal structures and loose leaderships. In this respect, both advantages and disadvantages can be pointed out: movements with these characteristics are more prone to be dispersed both in organization and goal and this can compromise the objectives established. However, the same characteristics allow, and even promote the construction of solidarities at national, regional and transnational levels, and capture the media attention, strengthening their action.

The categories of populism have been applied in this analysis because, as a political logic, populism is an analytical tool that allows the identification of the dynamics involved in the formation of our collective actor. This political logic concerns the process of institution of the social through the articulation between equivalences and differences. The equivalencial momentum presupposes the constitution of a global political subject that brings together a variety of social demands, implying, as mentioned, the constitution of internal frontiers and the identification of the institutionalized other. Some important aspects are identified: first, our collective actor's importance in what concerns the deconstruction of the dominant discourse; second, the delineation of an antagonistic frontier that divides the social and opposes civil society and those responsible for the imposition of the society of austerity (the state and external institutions-IMF, ECB and the European Commission), making space for proliferation of conflict; third, the application of logics of equivalence and difference demonstrates that the difficulty in defining who or what are the indignados stems from the fact that the significant indignados condenses a plurality of meanings in a stable system of signification and encompasses an equivalential chain of plural demands directed at the same opponent—-the society of austerity and its institutions.

There are various factors that restrain the scope of indignados' action. However, their importance as political subjects should not be overlooked, though it depends largely on the way crisis evolves, both in Europe and in other areas of the globe, and on their capacity of constructing a strong identity that encompasses the demands at stake, capable of mobilizing large sectors of the population. But, overall, the indignados are unquestionable vehicles of a critique of the system which has as horizon of the construction of an alternative. The neoliberal hegemony is thus being challenged from below, as the recent upheavals throughout Europe, as well as in other parts of the globe, demonstrated. The new wave of austerity has fostered, in southern Europe, a critical and collective response to the imposition of deprivations. Even though resistance to neoliberal hegemonic order has always existed, it has, in some cases, assumed an episodic and fragmented form, lacking some degree of coherence among various oppressed and subordinated groups, or, in other more successful cases as those movements or networks of movements that transcend nation-states' borders. It is clear that these movements haven't yet succeeded in combining themselves to form a coherent historical bloc around a counter-hegemonic bloc. Reporting ourselves to our case study, and in what concerns organizational forms taken by the social actors here at stake, the rhizomic networks lack any central basis for the coordination necessary for the formation of a 
counter-hegemonic historical bloc. Thus, it needs a coordination between these rhyzomic networks and more traditional (and formal) organizations, such as trade unions. Even though an alternative isn't out of reach, it demands innovation, creativity, and the rejection of old objective determinations in ways of reinvent social and political struggle.

\section{References}

[1] Ferreira, A.C. (2012) Sociedade de Austeridade e direito do trabalho de exceção. Vida Económica—Editorial, Porto.

[2] Cohen, J.L. and Arato, A. (2000) Sociedad civil y teoría política. Fondo de Cultura Económica, México.

[3] Carroll, W.K. (2010) Crisis, movements, counter-hegemony: In search of the new. Interface, 2, 168-198. http://interfacejournal.nuim.ie/wordpress/wp-content/uploads/2010/12/Interface-2-2-pp.168-198-Carroll.pdf

[4] Gramsci, A. (1971) Selections from the prison notebooks. International Publishers, New York.

[5] Gramsci, A. (1974) Obras escolhidas. Vol. 1, Editorial Estampa, Lisboa.

[6] Melucci, A. (1996) Challenging codes. Collective action in the information age. Cambridge University Press, Cambridge.

[7] Tarrow, S. (1998) Power and movement: Social movements and contentious politics. Cambridge University Press, Cambridge. http://dx.doi.org/10.1017/CBO9780511813245

[8] Estanque, E. (2012) A classe média: Ascensão e declínio. Fundação Francisco Manuel dos Santos, Lisboa.

[9] Eder, K. (1993) The new politics of class: Social movements and cultural dynamics in advanced societies. Sage Publications, Thousand Oaks.

[10] Laclau, E. (2010) La razón populista. Fondo de Cultura Económica de Argentina S.A., Buenos Aires.

[11] Mouffe, C. (2007) En torno a lo Político. Fondo de Cultura Económica de Argentina S.A., Buenos Aires.

[12] Touraine, A. (1981) The voice and the eye: An analysis of social movements. Cambridge University Press, Cambridge.

[13] Touraine, A. (1984) Le retour de l'acteur. Fayard, Paris.

[14] Collins, R. (1975) Conflict sociology. Academic Press, New York.

[15] Rancière, J. (1996) El desacuerdo: Política y filosofía. Nueva Visión, Buenos Aires.

[16] Laclau, E. and Mouffe, C. (2010) Hegemonía y estrategia socialista: Hacia una radicalización de la democracia. Fondo de Cultura Económica de Argentina S.A., Buenos Aires.

[17] Habermas, J. (1984) The theory of communicative action: Reason and the rationalization of society (Vol. 1). Beacon Press, Boston.

[18] Habermas, J. (1987) The theory of communicative action. Life world and system. A critique of functionalist reason. Vol. 2, Beacon Press, Boston.

[19] Norval, A.J. (1994) Social ambiguity and the crisis of apartheid. In: Laclau, E., Ed., The Making of Political Identities, Verso, London, 115-137.

[20] Marcuse, H. (2007) One-dimensional man. Studies in the ideology of advanced industrial society. Routledge, London. 